\title{
The Crisis of Historicism and the Correlation Between Nationalism and Neo-Kantian Philosophy of History in the Interwar Period
}

\begin{abstract}
Kate Papari
University of Athens, Greece

Recent historiographic studies of cultural exchanges between Germany and Greece in the 19th and 20th centuries have tended to neglect the mutual influence of the two countries' intellectuals; as a result, there is insufficient appreciation of the extent to which historiography and philosophy were appropriated by the politics of the Interwar period. This article focuses on attempts by neo-Kantian philosophers to overcome the crisis of historicism, and on the impact of this crisis on Greek intellectuals' perceptions of historicism. The study shows that at the time historicism invoked the past to solve the problems of the present. My purpose is to show that in a time of crisis, Germany's pursuit of its Greekness in conformity with the Bildung tradition, and Greece's cultural dependence on Germany in the meaning-making of its own Greekness, shared common ground in the ideological uses of philosophy and history in the service of politics and the politics of culture. In the aftermath of WWI, German scholars raised the issue of the crisis of historicism. Neo-Kantian philosophers such as Heinrich Rickert, whose theory had a major impact on Greek intellectuals, became involved in this debate, posing the question of historical objectivity. Yet Rickert's philosophy of history soon fell into an impasse, leading to the rise of an idealist philosophy of history in the 1930s that committed itself anew to the dominant politics. In the 1930s, under the guise of idealism, Greek neo-Kantian intellectuals were claiming an objective historical narrative of the traumatic experience from 1922 onwards, which fit into the structure of an idealized ahistorical and mythic past, and which, as a hegemonic discourse, excluded its political enemies and propagandized the political struggle towards the fulfillment of the nation's historical and spiritual mission.
\end{abstract}

Keywords: historicism, Interwar crisis, neo-Kantian philosophy of history, Greek intellectuals

\section{The Crisis of Historicism in the Aftermath of WWI}

The crisis of modernity in Europe, which escalated in the 1930s, has been mostly associated with the political upheavals of the era and the establishment of fascist and authoritarian regimes. Yet this crisis was itself rooted in the collapse of the dominant values and belief systems which had framed European intellectual life in the previous centuries. Focusing on academic affinities and mutual influences between certain German and Greek scholars, my purpose is to show in what way Greek intellectuals utilized historicism in order to serve the dominant national discourse based on a nationalist ideology, thus aiming to secure the continuity of the dominant power in a time of political crisis. This historical narrative was structured around an idealized mythic

Kate Papari, Ph.D. candidate student in Contemporary Greek History, University of Athens, Greece. 
past, which precluded Communism, its principal enemy, from the hegemonic discourse, while propagandizing the struggle for the fulfillment of the nation's new historical and spiritual mission.

This article has two objectives. The first is to argue that modernity's crisis marked the downfall of the pre-eminent academic currents, voiding life of the meaning it had generally been understood to possess, and radically changing the conservative intellectual classes' perceptions of the world, paving the way for new worldviews which shaped the politics of the time. Two of the most prominent academic currents that were thus plunged into radical doubt were historicism and neo-Kantianism. As a second goal, then, I aim to show that Greek intellectuals utilized the neo-Kantian philosophy of history in the framing of the new nation's conception of its mission in the contemporary world, thus putting it at the service of hegemonic politics.

Kant's philosophy has been regarded the epitome of Enlightenment. It is seen as embodying the liberal and democratic values that were revived by the neo-Kantian movement, promoted by Bismarck's state, and which later shaped the Weimar Constitution. But the collapse of the Weimar Republic in 1933 marked the end of neo-Kantianism in Germany. ${ }^{1}$ According to Beiser, neo-Kantianism's demise had both philosophical and cultural causes. Philosophically, it ran into a dead end; culturally, it was at odds with the Zeitgeist and the pessimism that set in after 1918. Neo-Kantianism was indelibly associated with the "ideas of 1914" and the cultural optimism that came with them: specifically, the belief that civilization was inevitably developing towards the ideal of reason had been discredited by the war. As Beiser and Bambach stress, historicism - and, to be precise, the crisis of historicism - was one of the dominant intellectual forces in the cultural climate of Weimar that served to undermine neo-Kantianism. In the aftermath of WWI an acute sense emerged that historicism's metaphysical premises of directionality had been definitively refuted. This engendered an almost existential sense of panic, and a deep pessimism regarding the impending collapse of the nation and the loss of its culture. Established as a kind of secularized theology, in the 1920s historicism slid into fatalistic historical skepticism and relativism. As Bambach claims:

One of the most prominent German philosophers of this generation, Ernst Troeltsch, came to understand this cultural crisis as the epiphenomenal expression of an underlying "crisis of history itself in its innermost structure', a crisis of 'relativism that paved the way for the seismic upheaval of values". [...] As Troeltsch put it, "the contemporary crisis of historicism is a deep, inner crisis of our time; it is not merely a scholarly or scientific problem but a practical problem of life". The older tradition of classical historicism that embraced a rigorously empirical model of research knew no value relativism. It was, rather, committed to the ethical unfolding of God's ultimate plan. ${ }^{2}$

But for most defenders of the Weimar Republic, historicism's crisis was experienced as a "crisis theology", a breakdown of historical norms and values that led to a permanent crisis of the relation between time and eternity. The universal and eternal validity of truths or values was called into question, since they had not only collapsed, but were now also regarded as embedded in, and so inseparable from, their specific historical context. Historicism became synonymous with relativism, and these relativistic implications began to unnerve the neo-Kantians. As heirs of the Enlightenment, they firmly believed that culture should rest upon universal values and that the central task of philosophy was to justify them.

\footnotetext{
${ }^{1}$ Beiser, Fr., "Weimar Philosophy and the Fate of Neo-Kantianism," in Gordon, P., \& McCormick, J., (Eds.), (2013), Weimar Thought. A Contested Legacy, Princeton University Press, Princeton-Oxford, p. 115.

${ }^{2}$ Bambach, Ch., "Weimar Philosophy and the Crisis of Historical Thinking," in Gordon, P., \& McCormick, J., (Eds.), (2013), Weimar Thought. A Contested Legacy, Princeton University Press, Princeton-Oxford, p. 134.
} 


\section{Neo-Kantian Attempts to Secure Objectivity and "Save" Historicism From Relativism}

The demand for historical objectivity justified the discipline of history as a science; but historicism's methods - which treated everything as the product of history-undermined the claim of history to provide a form of objective knowledge, and so brought about the downfall of historicism itself. Among the neo-Kantian philosophers who engaged in the attempt to overcome historicism's relativism was Heinrich Rickert. ${ }^{3}$ One of the most prominent neo-Kantian philosophers with significant appeal for Greek intellectuals in the 1920s, Rickert engaged in the problem of historicism in order to entrench the objectivity of historical research and consolidate scientific philosophy via a theory of universal values. Relying on Wilhelm Windelband's distinction between the nomothetic or generalizing method of natural sciences, and the idiographic or individualizing method of history, he formulated the schema of Naturwissenschaft and Kulturwissenschaft, separating the research methods of natural science from the sciences of culture. According to this schema, nature was determined by general and universal laws, while culture (and history) was determined by values. The ground for the latter was not ontological, as values do not have a substance, but rather logical or axiological: as a consequence, values are either valid or not. They are attached to concepts that human beings form in order to understand reality and help them to distinguish the essential from the inessential. In history, the individuality and singularity of a historical fact and its meaning is defined by relation to a cultural value. But then this seemed to lead to a paradox: a science which strove for objectivity was grounded in values that reflected subjective claims. In order to secure the objectivity of history, then, Rickert distinguished the evaluation of facts, which encapsulated subjective claims, from the relation of such facts to values, which was a scientific task; and he underscored that practical evaluation and theoretical reference to values were two logically distinct acts. For an example of this distinction, we might say that a subjective evaluation of the French Revolution might be whether a given person exalts or condemns its outbreak; but a theoretical reference to the values of the French Revolution would be that it became synonymous with political freedom. In addition, he asserted that transcendental values would guarantee the objectivity of historical science; universal transhistorical values that served as transcendental norms would secure what was historically essential not only for a particular time or place or culture but in general. He argued that historical reason needed a criterion, as a universal norm, whose validity should stand above the realm of history; otherwise historicism would slide into relativism. In other words, Rickert attempted to overcome the threat of relativism by establishing a universal system of values that could serve to anchor historical meaning. As Bambach concludes: "in this distinction between cultural values (whose ground is transcendental) and cultural objects (whose expression is historical), Rickert was convinced he had found the means to overcome the crisis of historicism and its anarchy of values."

However, his endeavor to reconcile the gap between the being of history (the reality of history) and meaning-laden history (the ideality of value) proved - as he himself admitted - to be problematic. The historian's goal of relating facts to universal values became synonymous with pursuing an ethical imperative which sought to bridge the gap between "what is" and "what ought to be". The most devastating critique of

\footnotetext{
${ }^{3}$ Bambach, Ch., (1995), Heidegger, Dilthey and the crisis of Historicism: History and Metaphysics in Heidegger, Dilthey and the Neo-Kantians, Cornell University Press, Ithaca and London; Beiser, Fr., (2011), The German Historicist Tradition, Oxford University Press, Oxford and New York; Beiser, Fr., (2014), After Hegel: German Philosophy, 1840-1900, Princeton University Press, Princeton and Oxford.

4 Bambach, "Weimar Philosophy", p. 142.
} 
Rickert's work came from Martin Heidegger, his former student at Freiburg, who claimed that in his attempt he had appealed to suprahistorical values that denied the historicity of human experience. ${ }^{5}$ Indeed, Rickert's philosophy of history presupposed a transcendental, non-historical subject, that would eventually attribute value and meaning to historical facts. Therefore, while the neo-Kantian philosophical programs had from their outset repudiated the speculative idealist tradition and had determined that philosophy was to be a "normative epistemology" whose purpose would be to serve as a "critical science of universally valid values", and while the neo-Kantians sought to reclaim the objectivity of historicism, they succumbed to a more fundamental form of metaphysical thinking in their philosophy of history.

The impasse in which Rickert's philosophy of history found itself led to the rise of an idealist philosophy of history that committed itself anew to dominant and ethnocentric politics. Despite the substantial differences between Greece and Germany in the political outcomes of the Interwar crisis, both states stood in a similar antagonistic relationship to Communism, which they perceived as a threat to their survival. Bourgeois intellectuals on both sides made ideological use of philosophy and history in order to serve the hegemonic powers. In the 1930s, Ioannis Theodorakopoulos, Panagiotis Kanellopoulos and Konstantinos Tsatsos, Rickert's former Greek students in Heidelberg, adopted this idealist schema of historical interpretation, failing to recognize in it neo-Kantianism's inability to secure historical objectivity. Furthermore, contrary to Castoriadis's assertion that historical knowledge is essentially a historical phenomenon and that the interpreter of historical knowledge is a historical being rather than a "transcendental consciousness", 6 they approached historical knowledge in eschatological terms, seeing the interpreters of historical meanings as charismatic personalities who embodied divine will and who should therefore lead, both spiritually and politically. The case of the Greek intellectuals is thus an example of the appropriation of Rickert's philosophy of history by the politics of the era.

\section{The Appropriation of Rickert's Philosophy of History}

According to the Greek intellectuals' philosophy of history, the meaning of historical facts depended on a transcendental value system that classified historical facts as either essential or inessential. But this value system drew on their ideological posture for its political legitimacy. In this framework, historical meaning encapsulated a normative, moralistic explanation in the service of political jingoism (ethnicofrosini). ${ }^{7}$ After the 1920s and during the 1930s, the diffusion of Left ideology and historical materialism in society, and especially in the universities, intensified the politicization of students and social groups that hitherto had been excluded from political representation. Dominant politics considered this development as a threat and now saw Communism as the major national enemy. Theodorakopoulos, Kanellopoulos and Tsatsos interpreted history in accordance to the ethics and norms of dominant politics. They claimed that historical science abstained from simply narrating the historical facts; on the contrary, its main purpose was to evaluate them. Their theoretical

\footnotetext{
5 Bambach, "Weimar Philosophy," p. 144.

${ }^{6}$ Castoriadis, C., (1975), The Imaginary Institution of Society, MIT Press, Cambridge, Massachusetts, pp. 23-24. As Castoriadis notes: "To have an experience of history as an historical being is to be in and of history, as it is also to be in and of society. And, leaving aside other aspects of this implication, this means: (a) thinking of history necessarily in terms of the categories of one's own epoch and one's own society — categories which are themselves the product of historical evolution; (b) thinking of history in terms of a practical intention or a project - a project which is itself a part of history."

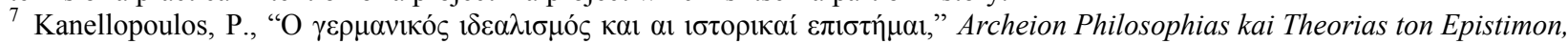
vol. 1, issue 2, April-June 1929, pp. 183-201.
} 
argument was based on the premise that history can be interpreted only idealistically, ${ }^{8}$ in order to disclose a form of the spirit that is grounded in the idea. ${ }^{9}$ In 1933, Tsatsos asserted that Rickert better than anyone else had conceived the fact that the methods of historical science are grounded in the notion of value. ${ }^{10}$ Because of its axiological character, history would be impoverished if it were promoted just as a simple recording of facts, without the contribution of an axiological interpretation of the meanings that historical facts bear. At the time - the late 1930s - their position regarding the axiological nature of history was in accordance with the direction of the secondary education programs being implemented in Nazi Germany. According to these programs, history should not be taught as a mere chronicle of facts but as a drama, and the teacher should move on to evaluations instead of simply setting out the historical facts objectively, as in the context of a positivist approach to history. ${ }^{11}$ As Chapoutot claims, dramatization and evaluation of the historical narrative was now regarded as a foundational principle in teaching history, ushering in a utilitarian perception of history itself. This perception emphasized history's new function as a compass for the present. ${ }^{12}$ History was useful in order to re-enact the past in the present, ${ }^{13}$ assigning the past a function as a guiding principle and a source of edifying morals for the present day. In other words, as Gourgouris put it: "National history is therapeutic [...]. It is not merely a narrative exaltation of the past but, strictly speaking, a poetic excavation of an imaginary future."14 This axiological and utilitarian perception of history was pursued not only in order to reinforce the state, but also to cultivate a particular ethical attitude among the civilians who were then seen as being aligned to the modern state's demands. ${ }^{15}$

Eventually, the idealistic use of history brought history down to the level of ethnocentric and nationalist ideology. By reinforcing the ideological needs of the present, this idealistic perception of history itself served as an ideology. By mythologizing particular historical moments of the national historical narrative, Greek intellectuals managed to exorcise politically controversial theories from the dominant discourse, arguing that they were non-historical and counter-humanistic, so contributing to the restructuring of the symbolic representations of a particular social class. ${ }^{16}$

As is known from Paparrigopoulos's historiographical work, the Greek idealist intellectuals identified two epochs in what they claimed as Greek history, which they saw as having particular moralistic and didactic significance for the notion of Hellenism; these epochs were Classical Antiquity, which set the spiritual foundations of Hellenism, and the Greek War of Independence in 1821, which shaped the nation's political constitution and embodied the classical spirit in the modern era. Theodorakopoulos, Kanellopoulos, and Tsatsos drew on these exemplary moments in order to promote their project of Greekness as a new "political

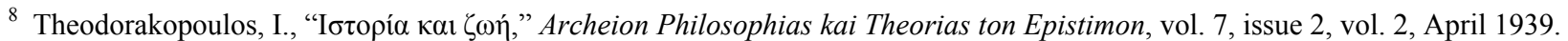

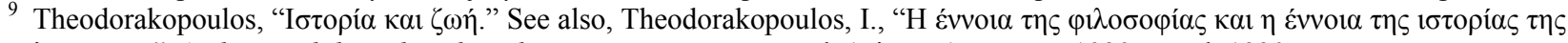

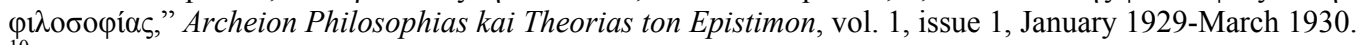

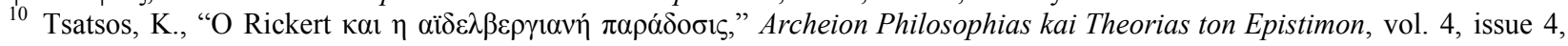
July 1933.

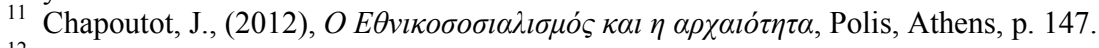

12 Ibid, pp. 143-148.

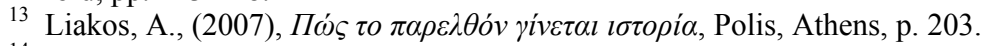

${ }^{14}$ Gourgouris, S., (1996), Dream Nation: Enlightenment, Colonization and the Institution of Modern Greece, Stanford University Press, Stanford, p. 243.

${ }^{15}$ Giouras, Th., "Н

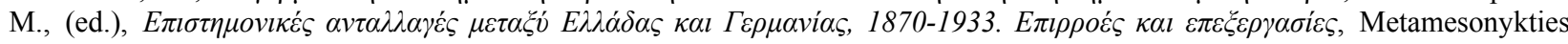
publications, Athens, pp. 45-58.

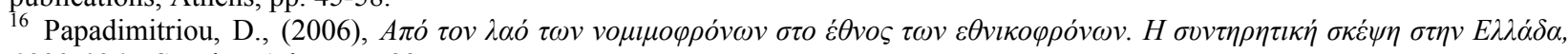
1922-1967, Savalas, Athens, p. 33.
} 
humanism", in accordance with the German paradigm at the time. ${ }^{17}$ In both cases, classical antiquity was utilized as the "bridge" between past and present, shaping a new cultural and political humanity. Especially in the Greek case, this humanism was an idealized recomposition of Hellenism in ideological conformity with the demands of the dominant state. This new humanism was therefore political, because it did not focus on the human being and its cultivation per se, but desired the edification of the human being for the sake of the state. At the same time, the cultural narrative was dictating a political framework inspired by particular principles according to which the new political subject would be configured as nationalistic and anti-communist.

\section{The Perspectives of the New "Political Humanism” Mediated by German Influences}

Within the generalized Interwar crisis, intellectuals dismayed by Greece's painful present looked to the past to uncover what was unique about Hellenism. This turn to the past was expressed as a nostalgic impulse, fleeing an $a b$ initio frustration and dissatisfaction to seek in the memories and practices of the past a safe and familiar refuge. According to a plethora of contemporary researchers, the nostalgic turn of the end of the 19th and the beginning of the 20th century was performed through a conservative, anti-modernist, and on occasions reactive discourse, and articulated as contrary to the achievements and dislocations of Modernity, which was bringing forth its own contradictions and disunions. ${ }^{18}$

Especially in the 1930s, this nostalgic yearning was focused on the nation, signaling a commitment to a reformist program that would redefine the national mission in the contemporary world. The reconstruction of the past therefore entailed a reinterpretation of the national present, disclosing the way in which the present expressed fantasies about a desired future. ${ }^{19}$ For the idealist intellectuals, the classical past, considered not just as a moment in cultural history but as a living standard, was a "snapshot" of a perfect model, free from the ravages of degeneration and decay, eternally new, from where the answers to the dead-ends of the present could be derived, and containing the resources needed to restore Hellenism. The eternal youth of classicism had the potential to be used as an imperishable value and as a guide for the present. The intellectuals believed that this would provide creative solutions to the dangers that Hellenism was then facing: communism, liberalism, overdemocracy, fiscal deadlock, and the decay of spiritual and moral values. The salience of antiquity as the ontological spring from which the new Hellenism would originate was due mostly to the "selective affinities" of the indigenous intelligentsia with Germany, as the content of Greekness was mediated by the related discussion of "Germanness" ongoing at the time.

In Interwar Germany, marked by a sense of intense crisis and a feeling that its political and cultural survival was under threat, ${ }^{20}$ the declarations of German cultural kinship with Greek antiquity became more and more frequent. From the German scholars' point of view, ancient Greece had produced norms and standards which were timelessly applicable to poetry, drama, art, philosophy and politics, and these norms should reframe a new cultural program that would lay claim to a new humanism. The theorists of the Conservative Revolution

\footnotetext{
17 The identification of Hellenism with humanism had been repeatedly asserted by the above bourgeois intellectuals in the Interwar era. Furthermore, other intellectuals assented to this contextualization of Hellenism. Giorgos Theotokas, for example, in his 1932 book Embros sto koinoniko provlima, highlighted the necessity of a "new humanism". Finally, in the Interwar era the common demand for humanism was being projected even by National Socialists in Germany, according to Chapoutot, constituting the shell of many fascist movements.

${ }_{18}$ Rosner, D., (2012), Conservatism and Crisis. The Anti-modernist Perspective in Twentieth-century German Philosophy, Lexington Books, United Kingdom, p. xi.

19 Boym, S., (2001), The Future of Nostalgia, Basic Books, New York, p. 354.

20 Sluga, H., (1993), Heidegger's Crisis. Philosophy and Politics in Nazi Germany, Harvard University Press, Cambridge and London, p. 91.
} 
had also invested their political claims in this program. One of the most prominent and eloquent books to depict the primacy of Hellenism in Germanness was Elize Butler's The Tyranny of Greece over Germany, first published in 1935. Butler asserted that the lashing of Germany with Classical texts, as well as the adoration of ancient Greek art, had led to the subordination of the German mind to the "tyranny of an ideal." Greece's influence on Germany, she argued, was the perfect example of a spiritual tyranny, since the German spirit had an incorrigible proclivity towards idealism, "a desperate passion for the absolute.,"21

Since Germany saw in the Greeks an "absolute measure of perfection," the rediscovery of Germanness would come through the myth and the rediscovery of Greece. ${ }^{22}$ This view was fortified, a year later, by Walter Rehm's study Griechentum und Goethezeit (Greece and the Age of Goethe, 1936), which posited that the memory of Greece for Goethe's century was the first indication of the potential of a German humanism. ${ }^{23}$ The conservative and nationalist German Philosophical Association (Deutschen philosophische Gesellschaft), founded in 1917, was also oriented in this direction, setting as its main purpose to clarify the singularity of the German nation, to determine its cultural particularities, and to articulate Germany's unique mission in the contemporary world. ${ }^{24}$ Its membership list expanded rapidly after 1935 to assimilate almost the entire German philosophical establishment, revealing that Greek "perfection" was indeed monopolizing Germanness. It is worth mentioning that among the members of the German Philosophical Association were a number of neo-Kantian philosophers, sociologists and legal scholars, such as Heinrich Rickert, Julius Binder and Hans Freyer, who had had major impact on the thought of the Greek idealist intellectuals mentioned above. ${ }^{25}$ The proximity of German spirit to the Greek was soon incorporated by National Socialism, with went so far as to propose the racial identity of the Germans and the Greeks. ${ }^{26}$ This Greek-German affinity was sealed in the celebrations for the 1936 Olympic Games in Berlin; ${ }^{27}$ as Chapoutot noted, "the Games ought to function as the mnemonic staging of the existing bond between ancient Greece and contemporary Germany.,"28

Having studied in Germany in the 1920s, Theodorakopoulos, Kanellopoulos, and Tsatsos came to partake in the standard of classical antiquity, declaring that a profound acknowledgment and interpretation of antiquity was the remedy for the spiritual and political crisis of Greece. For this reason they insisted that Heidelberg played a decisive role in the sublimation of the classical Greek spirit as "eternally present" in modern Greece. In Kanellopoulos's words:

By transferring to Athens the spiritual tradition of Heidelberg, we asserted the mostly Greek origin of this tradition. Heidelberg not only did not alienate us from Greece, but made us even more conscious of the eternal youth of the ancient Greek spirit. ${ }^{29}$

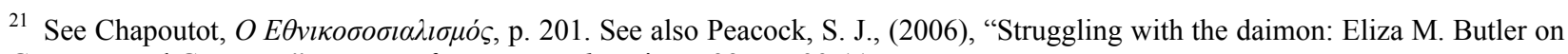
Germany and Germans," History of European Ideas, issue 32, pp. 99-115.

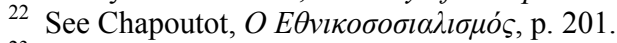

${ }^{23}$ Ibid., p. 200.

${ }^{24}$ See Sluga, Heidegger's Crisis, p. 101.

${ }^{25}$ Other members of the German Philosophical Association were Bruno Bauch, Nicolai Hartmann, Max Hildebert Böhm, Paul Häberlin, Alexius Meinong, Hans Pichler, Walter Schmied-Kowarzik, Heinrich Scholz and later on Hermann Glockner, Felix Krueger, Theodor Litt, Dieter Mahnke, Erich Rothacker, Othmar Spann, Rudolf Unger, Heinrich Wölfflin. See Sluga, Heidegger's Crisis, pp. 97-98.

${ }^{26}$ See Sluga, Heidegger's Crisis, p. 20.

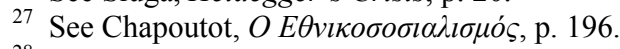

${ }^{28}$ Ibid., p. 241.

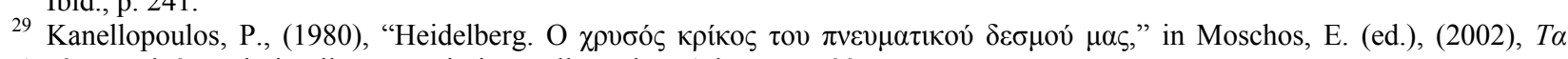

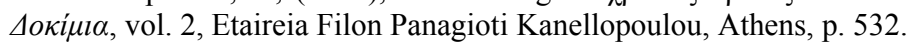


This orientation was already apparent in the first issue of the journal Archeion Philosophias kai Theorias ton Epistimon, which the above intellectuals published from 1929 to 1940. The first article of the first edition

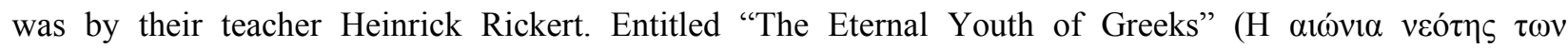
E $\lambda \lambda \eta v \omega v),{ }^{30}$ it aimed to establish the timeless and eternal youth of Hellenism via the argument that Greeks had created the foundations on which modern civilization relied. In Rickert's words, "by examining the Greeks we examine our own youth." ${ }^{31}$ In an article of 1936, in the same spirit, Ioannis Kakridis underscored the significance of classical education in the nation's effort "to move forwards to more spiritual and happier roads. ${ }^{32} \mathrm{He}$ asserted that just as classical education had contributed to the awakening of the Nation (Genos, Г'́vos) in the 1821 War of Independence, marking the beginning of a new historical period, the nation should return to the classics in pursuit of a new victory against spiritual slavery, by offering myth, art, philosophy, government, and the mythic heroes and politicians of antiquity as a standard. "In a demystificated era, as it is nowadays," Kakridis asserted, "the ancients' creativity is an indispensable educational good." National education should be based on this in order for modern Hellenism to regain faith in the emergence of the new mythic man. Furthermore, in the Dialogue for Poetry, with Seferis, Tsatsos repeatedly stressed the ontological and metaphysical character of Hellenism, claiming that it constituted "a category of history, a 'moment' of the idea, an a priori norm, an absolute form of life" in the course of the spirit. ${ }^{33}$

Because of their roots in the classical tradition, Modern Greeks, according to Theodorakopoulos, had managed to shape a new and deeply humanistic character that had led to the War of Independence. ${ }^{34}$ What "1821" signified for the intellectuals of the 1930s was the birth of the Third Hellenism, which was struggling to fulfill its historical mission. ${ }^{35}$ The year 1821 crystallized the historical meaning and the "mythic light" of the particular character of the modern Greek tradition, the core from which modern Hellenism stemmed. The year had the same symbolic meaning for Kanellopoulos, who noted that "the idea of Aghia Lavra remained for us, [...] the eternal Ark of Greek Truth." "36 For the idealist intellectuals, those two historical "snapshots" of Hellenism were its foundational myth, "a primordial myth that consisted the spiritual and moral dowry that fate offers to the people," Theodorakopoulos wrote. ${ }^{37}$ The mythologization of the ancient Greek past, from which the events of 1821 stemmed, reasserted Greek singularity, on which rested their claims not only for the fulfillment of national destiny but for the universality of Hellenism, since in their eyes the classical heritage became synonymous with culture in general.

The aforementioned goals were pursued not only by promoting those two mythic periods of Greek past in the reframing of Greekness, but also by disdaining the Byzantine period. Although Byzantine history was gaining ground within the universities of the 1920s and 1930s, many scholars expressed reservations about the contribution of Byzantine culture to Hellenism. As Karamanolakis notes, there was general academic

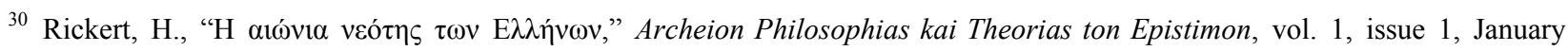
1929-March 1930, pp. 7-24.

31 Ibid., p. 8.

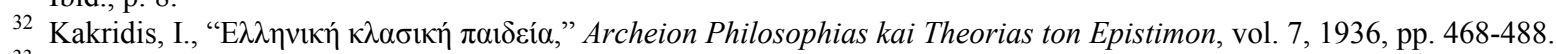

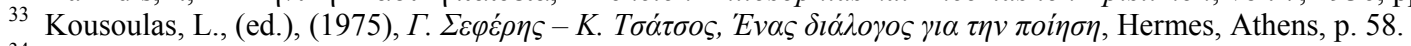

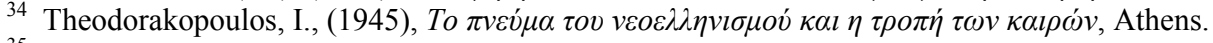

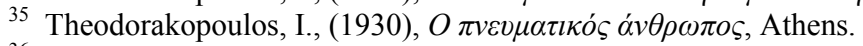

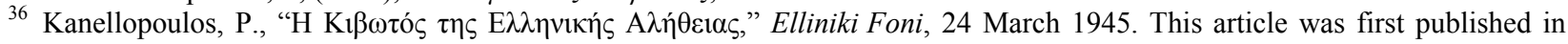
French on March 251944 in the daily newspaper of Cairo, Le Progrés Egyptien. A year later it was published in the newspaper

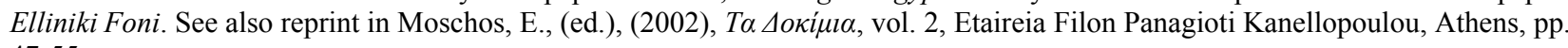
47-55.

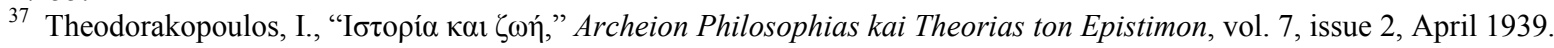


skepticism about the despotic and theocratic character of Byzantium, as it was represented in European historiography. ${ }^{38}$ Consistent with this, the idealist intellectuals took an entirely dismissive stance towards Byzantine, excluding it from the mythic cultural past of Hellenism as well as from the humanistic program of Greekness, and averring that the contribution of Byzantine literature fell short in comparison to the heritage of Classical Antiquity. In 1930 Theodorakopoulos asserted that the Byzantine medieval millennium had "ended up in Byzantinism, that prepared the ground for the race's subordination to Asian slavery." Although he recognized Byzantine history as a chapter in Hellenism's historical and spiritual development, he stressed that "we do not accept the medieval history as a paradigm of our new life and prosperity." 39

Kanellopoulos's account of Byzantium's contribution to Hellenism was also negative, and remained so at least until the 1960 s when he reconsidered his initial theses. ${ }^{40}$ His initial theses were enunciated in the two first editions of the Istoria tou Europaikou Pneumatos, published in 1941 and 1947, where he expressed his belief that Byzantine, having been unable to realize the significance of its historical mission, had served only to spread Greek literature in Europe, thus positioning the Europeans as the rightful inheritors of the ancient Greek spirit. The writings of Augustine contained the first synthesis of the Greek and Christian spirits, according to Kanellopoulos, while Byzantine itself remained "spiritually dead". As he characteristically put it:

[...] In its whole and despite the many moments of this wonderful period, in the Byzantine Empire is missing - and this is a heavy curse that fell on Byzantium - the true poet of the Reason. [...] Byzantine remained poetically speechless and could not therefore contribute to the birth and the development of the European man and the European spirit. ${ }^{41}$

Kanellopoulos's dismissive attitude disturbed like-minded intellectuals such as Theotokas, who regarded the underestimation of a such an important chapter of Hellenism as provocative, and saw Kanellopoulos's unshakeable attachment to antiquity as revealing interpretative restrictions in the contemporary meaning of Greekness and Hellenism. In his diary of 23 October 1941, he noted:

[...] I have argued with him twice on issues concerning Byzantine and Byzantine art. A normal conversation between us could not be conducted. He refused to take my arguments under consideration and he interrupted me by saying that all these are "Asia," that Byzantine art is Greek as much as $\alpha \mu \alpha v \varepsilon \delta \delta \varepsilon \varsigma$ [amanedes], that I am victim of local prejudices, because I adore the icons and the Byzantine architecture, that it is time to "be free" of all these etc. In a historical and artistic issue like that, such an exclusive perception and a simplifying intolerance is not allowed and is not a good intellectual sign.

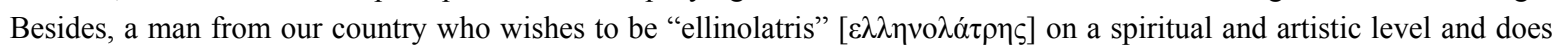
not understand anything of the artistic development of the ten centuries of Byzantine (that not only he does not understand but furthermore doesn't love and indeed he despises) gives me the impression that preserves the "ellinolatreia" $[\varepsilon \lambda \lambda \eta v o \lambda \alpha \tau \rho \varepsilon i ́ \alpha]$ bibliographic and museological, and not the living organic continuity of the Greek spirit. ${ }^{42}$

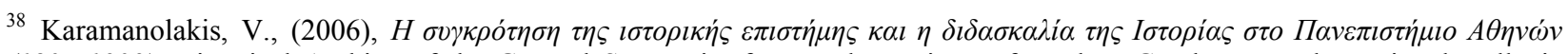
(1837-1932), Historical Archive of the General Secretariat for Youth, Institute of Modern Greek Research, National Hellenic Research Foundation, Athens, p. 123.

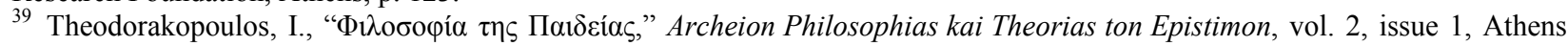
1930, pp. 38-39.

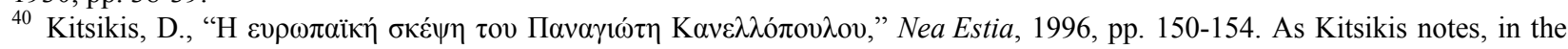
1966 edition of the Istoria tou Europaikou Pneumatos, Kanellopoulos wrote: "a foundational difference between the old and the new form of my book concerns Byzantium. Now I attributed in Byzantium its proper position in the history of European Spirit. Thirty years ago, in the second edition of this book, I was not qualified to recognize that. In its first edition, in 1941, I had only dedicated to Byzantium seven pages. Now those almost ten pages became circa two hundred sixty." See also Benakis, L., (2006),

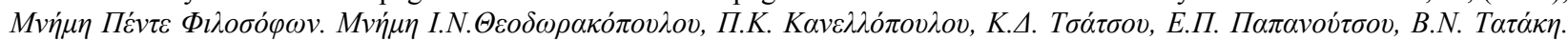

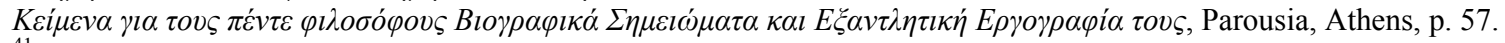

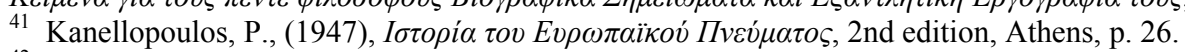

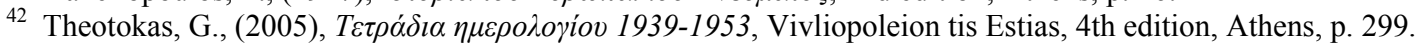


The controversies between bourgeois intellectuals regarding their views on the organic continuity of Hellenism are indicative of ideological and political shifts and divergences, especially in the 1930s and 1940s. In 1940, Theotokas and Seferis, two intellectuals with Anglo-Saxon influences, distanced themselves from Theodorakopoulos's, Tsatsos's, and Kanellopoulos's obsession with classical antiquity. Theotokas asserted that these assumptions about Greekness were incongruous with actual Greek reality. Recounting a discussion on this topic with Kapetanakis, he wrote in his diary:

[...] Two days ago, talking with Kapetanakis, ${ }^{43}$ I noted the existence of a "school" that is taking shape in the intersection of Sikelianos's, Sykoutris's and Tsatsos's influences. It is an amalgamation of German idealism (from second-hand mostly), Sikelianos' poetry and parochial metaphysics. The result, extremely blurry, is a spiritual and artistic Greekness, dogmatic, stern, and not at all Greek according to my perception of things. We were wondering with Kapetanaki about how we should name this tension and he [...] defined it as a theosophy without God. Quite fitting. ${ }^{44}$

For Theodorakopoulos, Kanellopoulos, and Tsatsos, historical memory and national history worked both therapeutically and narcissistically. In this context, classical antiquity was always present as the reservoir from where timeless humane values emerged and from which the imperishable and primordial features of the nation stemmed. Through this lens, both classical antiquity and 1821 were selected as the heroic mythical basis of the spiritual, cultural, and political constitution of the nation, having as a goal the readjustment of national identity for a mobilizing and engaging mission; in a logical and ontological continuity, the past produced the present, and the present was giving birth to the future, according to the unbreakable necessity of national determinism.

\section{History as a National Pedagogy and the “Non-historical” Historical Materialism}

National history was offered as a ductile narrative in which the patterns of national myths, symbols, and memory could be modified to form cultural milestones in order to entrench the difference from "alien" elements, the politically and culturally other, which corroded identity and threatened national coherence. In this aspect, the national historian - and/or national intellectual - as Gourgouris noted, "is no less than a warrior against the nation's others. [...] The historian is a mediator, a translator of the national dream, as the Nation directly demands." 45 In the Interwar era, the bourgeois intelligentsia inscribing the historical mission of the nation in the frame of an idealist perception and philosophy of the historical becoming, were explicitly opposed to the widespread "materialistic perception of history." In 1935, Kanellopoulos exclaimed: "Communism separates me [...] from my faith in the idea of nation as an organic unity and in the national state as an indispensable bearer of the historical life and culture." 46 Contrary to idealism, which defined the idea as the "prime mover" of history, historical materialism was condemned as non-historical and "more dogmatic than any other authoritarian, absolutist interpretation of history," 47 because it undermined national history, fastening its interpretation to natural laws that determined the progress of technical civilization and the development of economic life. Theodorakopoulos's rejection of historical materialism was based on the argument that it capsized not only the spiritual values of Hellenism, but furthermore that it desecrated its national history.

\footnotetext{
43 The poet Dimitrios Kapetanakis was former student of Kanellopoulos.

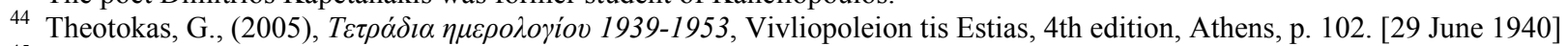

${ }^{45}$ Gourgouris, Dream Nation, p. 251.

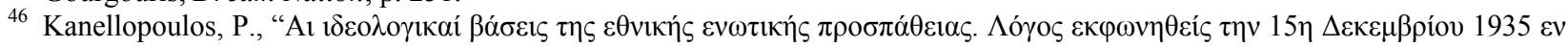
A $\theta$ ஸ́vaıs," Elliniki Foni, Saturday 4 January 1936.

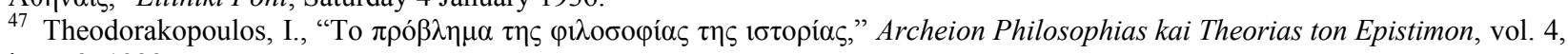
issue 2, 1933.
} 
Educational historical materialism, or at least this political system as it emerges today, is something riotous and deeply non-historical, despite the fact that it is called historical materialism. Historical materialism is non-historical because it violates the notion and energy of history, and seeks with only one element of historical life, the materialistic, to interpret the whole historical becoming, and pursues the violent overturn of all spiritual values [...]. Historical materialism is non-historical because it alters history and identifies it with physics. Historical materialism is non-historical because its dialectics are presented as a numeric relation [...]. The economy works on arithmetic categories, for this reason it violates history and from a historical phenomenon it turns it into a physical phenomenon. [...] Those who aim for us to forget the works of our historical life, pursue the complete oblivion of the past and have as their symbol Communism, violating Greek history so as to present the drama of the creation of modern Greece [...] as a simple economic fact $[\ldots] .{ }^{48}$

In his 1927 review of Yanis Kordatos's Modern Greek Political History, published in Byzantinisch-Neuegriechische Jahrbücher, Kanellopoulos decried the Marxist as "a passive instrument of necessity that has been drifted away from his era" and who falls short in faith, the only thing that has produced true values, since "only faith is destined to save us from the mechanistic misery of our time." 49 Tsatsos had a similar view, asserting that historical materialism was undermining the idea and value of homeland.

The denial of historical homelands, or, [...] the denial of homeland as an idea, is offered as an alluring argument, used by the most dexterous propaganda of all, that is cloaked itself the skin of science, is constantly waving above the foggy heads of young people. ${ }^{50}$

For Tsatsos, the notion of homeland as a spiritual unity was interwoven with the history of its culture and the acknowledgment of the absolute value of history, and for this reason it constituted a value of its own as the riverbed of culture. Historical materialism had turned against homeland, and Tsatsos saw this as heralding the extinction of national culture. ${ }^{51}$

In their university lectures they indeed proved to be "warriors against the nation's Others", fighting historical materialism both practically and theoretically. Kanellopoulos's 1930 seminar was dedicated to Marxist economic theory, while in 1932/1933 Kanellopoulos and Tsatsos organised joint seminars on the topics of Historical Materialism, Ethics and Law, Idea and Causality. In these seminars idealism was served up as a bulwark against historical materialism, both philosophically and politically. But their clear ideological orientation ran contrary to students' expectations and led to a segment of left-wing students at the Law School of the University of Athens expressing their opposition to Kanellopoulos and Tsatsos. In 1933, the then-Marxist students Savvas Konstantopoulos ${ }^{52}$ and Anastasios Christophilopoulos published an open letter in the journal Neoi Protoporoi, addressing Tsatsos and accusing him among other things of having an ulterior motive in his seminars on Marxist theory. ${ }^{53}$ Their enthusiasm for the seminars in Marxist theory, they said, soon raised their discomfort about the lecturers, as it was obvious that their goal was to impugn Marxism in order to "extricate" the respectable portion of their students from the ideas of dialectical materialism that they were in danger of

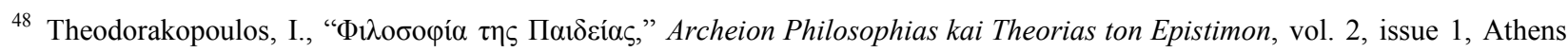
1930, pp. 28-30.

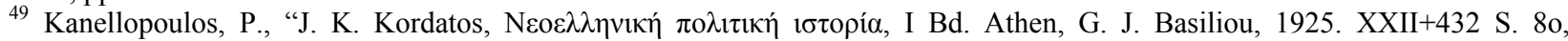

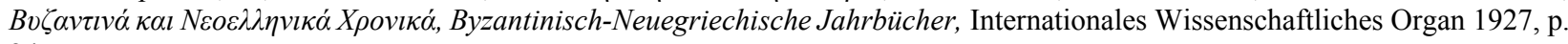
247.

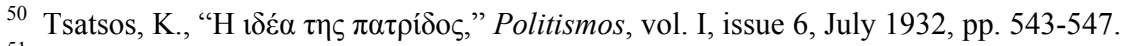

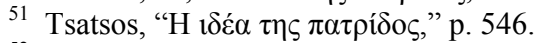

52 Later on Savvas Konstantopoulos joined the conservatives, turning into a sworn enemy of communism.

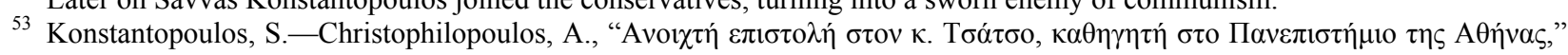
Neoi Protoporoi, February 1933, issue 2.
} 
embracing. ${ }^{54}$ The seminars had been terminated suddenly, since they had evolved in the opposite direction from what the lecturers had wished. In the same letter they accused Tsatsos of indulging the fascist ideas being promulgated in the university with the support of the Ethniko Pamfoititiko Syllogo (National Student Association), and that as a result students had been expelled from the university because of their political beliefs. Georgios Daskalakis, a former Law School student of Tsatsos and Kanellopoulos, undertook to respond to this public denunciation, publishing an article in the conservative journal Idea. ${ }^{55}$ Daskalakis claimed that it was a fallacy to identify idealism with capitalism, and asserted instead that the idealist professors were struggling for democratic freedom and a classless society. He also characterized the fight between Communist and Fascist students on the campus as ridiculous, and explained that he had no intention to refute examples of violent reaction that might take place in the university. This exchange soon incited the interest of the daily press. ${ }^{56}$ In 1935, plenty of liberal and conservative newspapers applauded the boisterous mass expulsion of about seventy leftist students from the University of Athens, while Rizospastis, the Communist Party's newspaper, condemned it. ${ }^{57}$ An article in the liberal journal Ergasia viewed this event positively, "so that there will not remain among the academic youth cores of national disintegration." The article remarked that the university authorities had been slow to take action, having known that for many years that "deceitful ideals, alien to the traditions of the Greek nation" were being promulgated among the students. Up to then, the only reaction against this development had come from younger academics in the Law School, who "by their idealistic beliefs in their lectures managed to restrain some students' consciousnesses' from these idea and prevent them affiliating with them." But the indifference manifest in the majority of the university departments had led to the deterioration of the situation, and the expulsion of students was eventually deemed prudent because the students "had not been protected as they should be from the untamed propaganda of historical materialism." 58

It is hardly surprising to find that Kanellopoulos and Tsatsos numbered among the younger members of the teaching faculty of the Law School who "had restrained some students" from leftist ideas. As Ilias Iliou remarked about Kanellopoulos, "he taught Marxism in the university but it is widely known his confutation of Marxist theory from Dimitris Glinos in Rizospasti and Protoporous. ${ }^{.59}$ Kanellopoulos himself summarized his educational and academic work against historical materialism in his memorandum to King George II on January 1937.

\footnotetext{
${ }^{54}$ They characteristically asserted: "With self confidence you devoted yourself in the goal to shake student's faith in the scientific truth of dialectical materialism. You undertook the role of the most optimised reaction. [...] Indeed, in the social action that idealist philosophy leads you: among the two regimes, that both are hostile for the intellectual, the worst and most dangerous is the communist." The students were also referred to a public letter from Tsatso to Foto Politi, published in Proia, on September 9 , 1932. In this letter Tsatsos wrote: "Until recently none has been opposed seriously in this sneaky poisoning of our spiritual seedbed. [...] Young people, that will lead tomorrow, must understand two things; the dogma that the individual is subordinated to social laws is a lie and that the overturning of capitalism is completely irrelevant to the spiritual freedom of the human being."

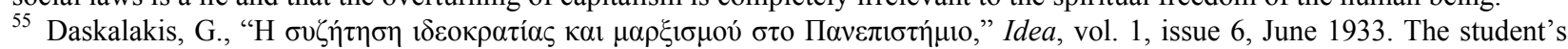

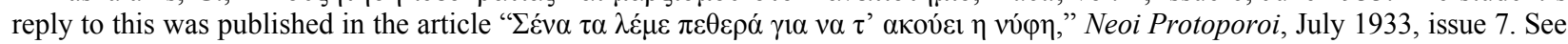
also Archive of Konstantinos Tsatsos, Gennadeios Library, The American School of Classical Studies at Athens.

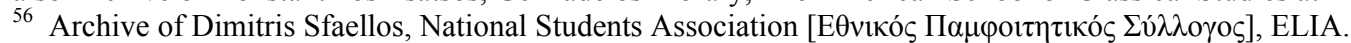

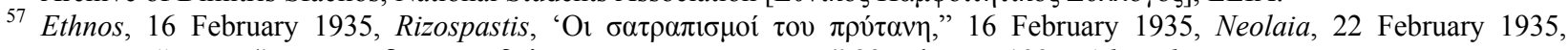

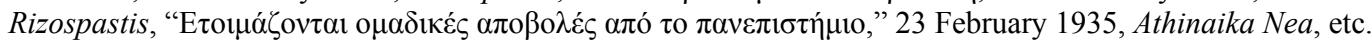

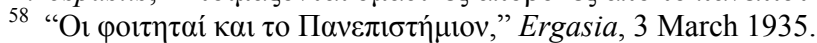

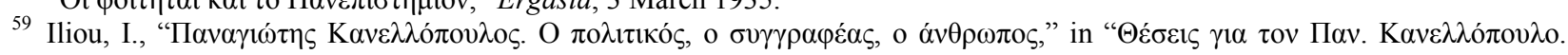

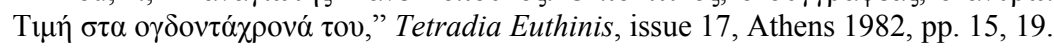


I am addressing to Your Majesty as a teacher and pedagogue, who already for a decade - even before I became a university professor and later on politician — has struggled, unfortunately with hardly any support from colleagues, for the extinction of the materialistic worldview from young peoples' consciousness; a worldview that unfortunately under the guise of Marxism, and by using Homeland, Family and Religion as void and pompous words [...] was systematically rendering them in the embrace of historical materialism. Its allure was intercepted from 1928 and on, namely since some teachers - among whose I am proud to number myself-undertook the systematic ideological critique against Marxists [...] juxtaposing a national ideology $[\ldots] .^{60}$

\section{Conclusion}

The idealistic philosophy of history supplied an imaginary which supported the historical mission of the nation. As Castoriadis notes, every national imaginary is structured as "a historical doing/representing, as such, it institutes and is obliged to institute the 'instrumental condition' for its social-historical existence." ${ }^{, 61}$ In these terms the afore-mentioned intellectuals instrumentalized philosophy and history, which in their hands came to constitute the keystone, the "prime mover", for the doctrines of Greekness. By postulating that German idealism expressed the continuity of Platonic idealism, they embraced an equally idealist philosophy of history, seeing it as most fitting for Hellenism, and at the same time victimizing historical materialism, which they saw as having corroded the university and the students therein. The ideological use of philosophy certified the pharmaceutical argument of Derrida. In this way, according to Gourgouris,

[...] philosophy, in conjunction with its etymological function, signifies a carefully delineated paideia that accounts for the historical and linguistic particularity of the culture it sets out to cure, to bring back into its senses, to bring to light. [...] So the philosopher now inevitably becomes the pharmakeus, implicated into the politics of culture, engaged in the ambivalent enterprise of history $[\ldots] .{ }^{62}$

Historiography, respectively, emerges as a field of negotiation of the hegemonic discourse and a field of negotiation of Otherness - culturally and politically - that crucially affects the collective and the national imaginary. In its downfall, as well as in its ascent to the status of a discipline, historicism was inextricably linked, according to Hayden White, to the politicization of historical thinking in favor of a social function which served social stability as a political tool. ${ }^{63}$ The Greek example suggests that in the Interwar crisis both philosophy and history became part of the knowledge or the ideology that the dominant state produces, obtaining the character of invented tradition ${ }^{64}$ or perpetual self-alteration, ${ }^{65}$ and so served the ideology that the dominant state produced under the name of "national truth". But this national truth was not what had been preserved in popular memory, but what had been chosen, represented, popularized, and institutionalized by the dominant discourse as the norm of its identity and as a mechanism of its perpetuation. By underscoring the universal significance of particular moments of the national historical narrative, Greek intellectuals cast the state's political opponents out of history itself. They claimed that historical materialism's historical interpretation was non-historical and counter-humanistic, and that it overturned the spiritual values of Hellenism and desecrated the national history. By casting historiography with a didactic and polemical

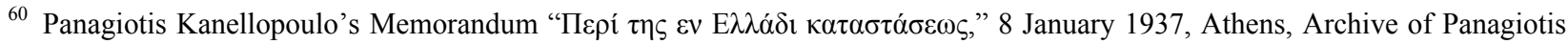
Kanellopoulos, f.5/938.74, 1935-1938.

${ }^{61}$ Castoriadis, The Imaginary Institution of Society, p. 153.

${ }^{62}$ Gourgouris, Dream Nation, pp. 107-108.

${ }^{63}$ White, H., (1990), The Content of the Form: Narrative, Discourse and Historical Representation, The Johns Hopkins University Press, Baltimore and London.

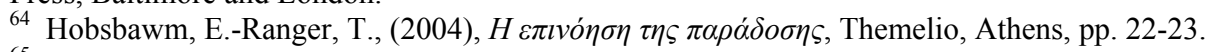

${ }^{65}$ Castoriadis, The Imaginary Institution of Society, p. 227.
} 
character, they contributed to the configuration of symbolic representations of a particular political and social class. ${ }^{66}$ Intellectuals appropriated an idealist philosophy of history and the neo-Kantian theory of values in order to classify, organize, and interpret national history in accordance with the dominant ideology's commands. At the same time, this appropriation of history and philosophy allowed the hegemonic discourse to consolidate the validity and truth of its pretentions, justifying, verifying and authenticating its claims by spurious references to the past.

In this context, Greekness, promoted as a cultural tool for the new political humanism, served as the institutionalizing discourse of the national imaginary and at the same time as a political discourse that settled the ideological conflicts among liberals and conservatives and cemented a hegemonic block, rendering the dominant politics as the bearer of a political and spiritual program for a new Greek humanism which was nationalist and anticommunist.

\section{References}

Bambach, Ch. (2013). Weimar Philosophy and the Crisis of Historical Thinking. In P. Gordon, and J. McCormick (Eds.), Weimar Thought. A Contested Legacy. Princeton University Press, Princeton-Oxford.

Bambach, Ch. (1995). Heidegger, Dilthey and the Crisis of Historicism: History and Metaphysics in Heidegger, Dilthey and the Neo-Kantians. Cornell University Press, Ithaca and London.

Beiser, Fr. (2013). Weimar Philosophy and the Fate of Neo-Kantianism. In P. Gordon and J. McCormick (Eds.), Weimar Thought. A Contested Legacy. Princeton University Press, Princeton-Oxford.

Beiser, Fr. (2014). After Hegel: German Philosophy, 1840-1900. Princeton University Press, Princeton and Oxford.

Beiser, Fr. (2011). The German Historicist Tradition. Oxford University Press, Oxford and New York.

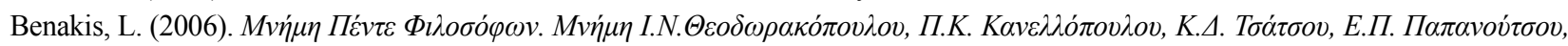

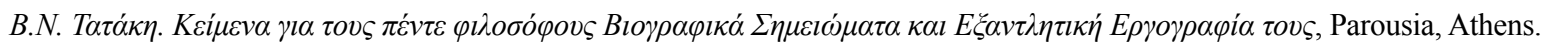

Boym, S. (2001). The Future of Nostalgia, Basic Books, New York.

Castoriadis, C. (1975). The Imaginary Institution of Society. MIT Press, Cambridge, Massachusetts.

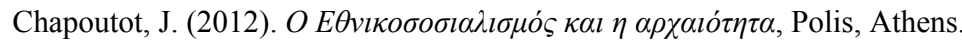

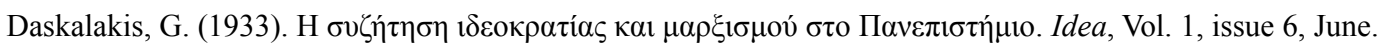

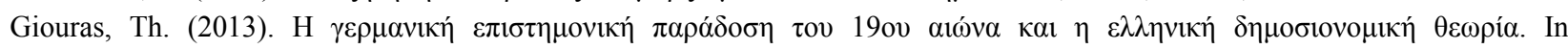

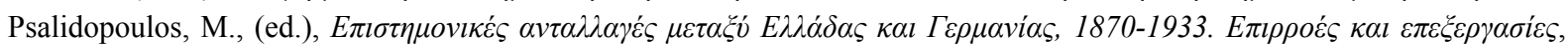
Metamesonykties publications, Athens.

Gourgouris, S. (1996). Dream Nation: Enlightenment, Colonization and the Institution of Modern Greece. Stanford University Press, Stanford.

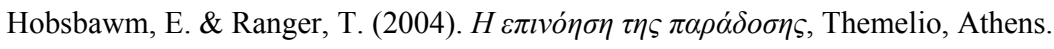

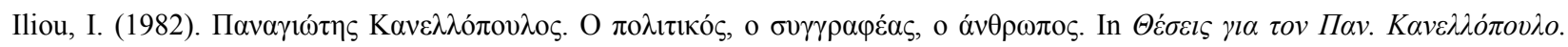

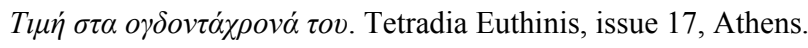

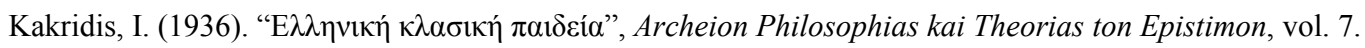

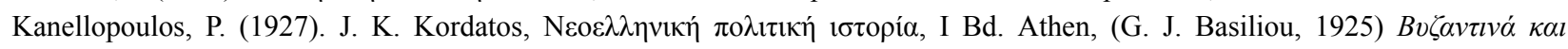

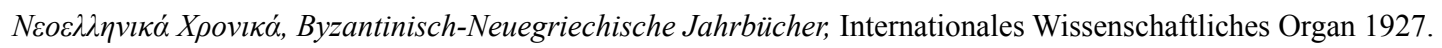

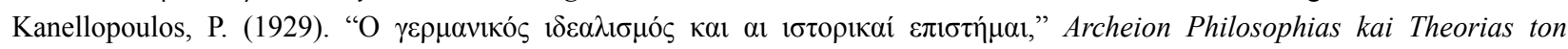
Epistimon, vol. 1, issue 2, April-June.

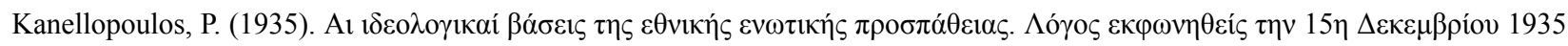

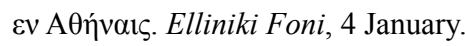

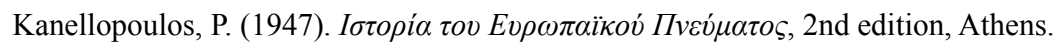

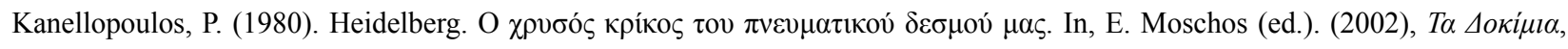
vol. 2, Etaireia Filon Panagioti Kanellopoulou, Athens.

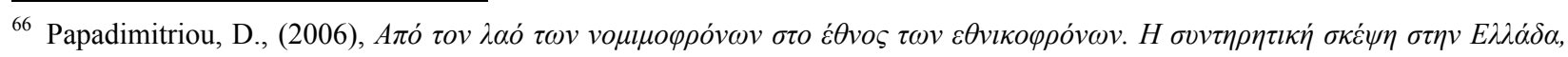
1922-1967, Savalas, Athens, p. 33. 


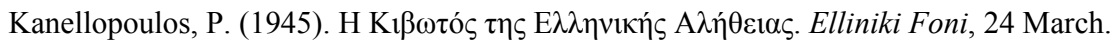

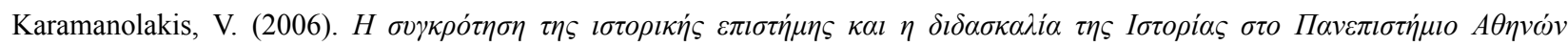
(1837-1932), Historical Archive of the General Secretariat for Youth, Institute of Modern Greek Research, National Hellenic Research Foundation, Athens.

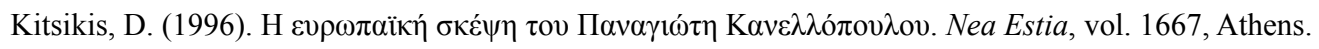

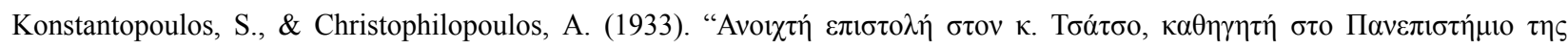
A $\theta$ ívas," Neoi Protoporoi, February, issue 2.

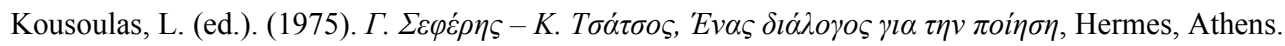

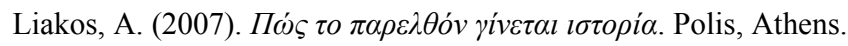

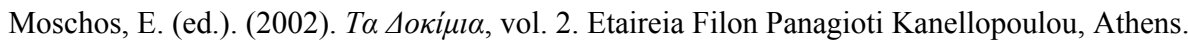

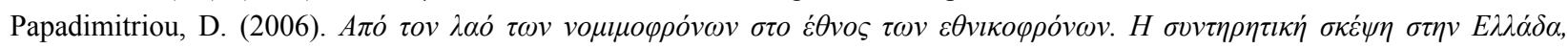
1922-1967. Savalas, Athens.

Peacock, S. J. (2006). Struggling with the daimon: Eliza M. Butler on Germany and Germans. History of European Ideas, issue 32.

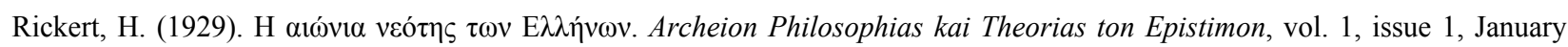
1929-March 1930.

Rosner, D. (2012). Conservatism and Crisis. The Anti-modernist Perspective in Twentieth-century German Philosophy, Lexington Books, United Kingdom.

Sluga, H. (1993). Heidegger's Crisis. Philosophy and politics in Nazi Germany. Harvard University Press, Cambridge and London.

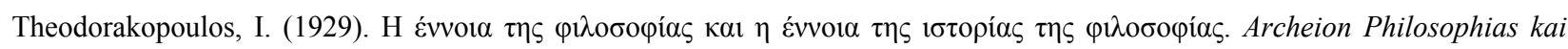
Theorias ton Epistimon, Vol. 1, issue 1, January 1929-March 1930.

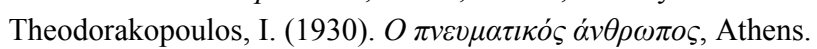

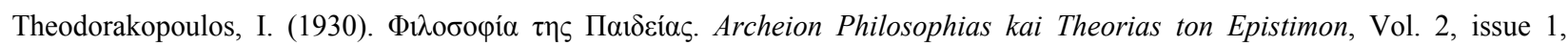
Athens.

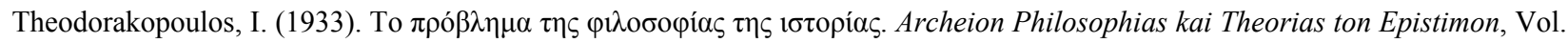
4 , issue 2.

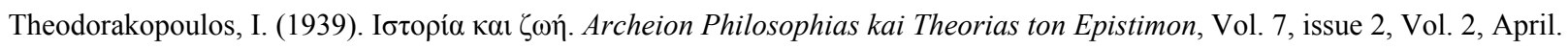

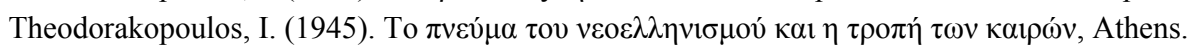

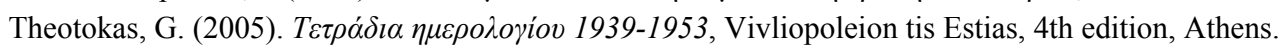

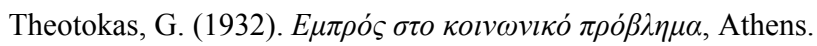

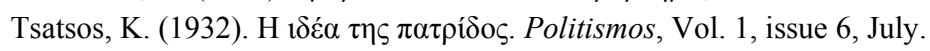

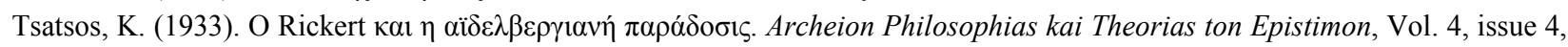
July.

White, H. (1990). The Content of the Form: Narrative, Discourse and Historical Representation, The Johns Hopkins University Press, Baltimore and London. 